The Coalition Government at Ottawa. The session of the Canadian parliament which terminated on May 23, 1918, was the most remarkable in the history of the Dominion. There was at least one coalition government during the era of the united provinces of Ontario and Quebec - the era that extended from 1841 to 1867 , But it was short-lived, and its only mission was to bring about confederation. With the exercise of tact by the premier and his cabinet, and with good management generally, a longer life may be secured for the coalition government that came into being at Ottawa in the autumn of 1917 , and that was endorsed and returned to power at the general election in December of that year. The war and the conscription act of 1917 were the only issues at that election. In six or seven of the provinces there was a successful fusion of the old political parties-Conservative and Liberal - on these issues; with the result that when the new parliament assembled on the 18th of March, the Unionist government was able to command a majority of sixty in the house of commons-the only branch of parliament at Ottawa that really counts in the political life of the Dominion.

Fusion at the election of 1917, so far as the rank and file of the voters were concerned, was a matter of no great difficulty in most of the English-speaking provinces. The war has been the dominating factor in Canadian politics since the autumn of 1914; and for seventeen years before the war-from 1897 when the Liberal government adopted and greatly extended the national policy of the Conservatives-there were no continuing political issues on which it was possible, even with a microscope, to trace any dividing line between the Conservatives, who originated the policy of protection in 1870 and 1879 , and the official Liberal party, which adopted it in 1897, which twice increased the tariff (1897 and 1907), and steadfastly adhered to a high protectionist policy from 1897 until it was defeated at the gencral election in 1911 . From 1897 to 1914 only the offices and tradition divided the Liberals from the Conservatives; and in these years there was a decided decline in popular interest in politics, as compared with the period 18791896-the years during which the Liberals wers in opposition.

Sir Robert Borden, premier of the Conservative government of 19111917 , was the only man available for the premiership of the Unionist government formed in October. He is a good parliamentary figure; but quite lacks the strength and force of Macdonald, Thompson or Tupper - three of the Conservative premiers who preceded him. Sir Wilfrid Laurier, who was premier of the Liberal governments of 
1896-1911, and leader of the old Liberal opposition from 1911-1917, was not a possibility for the headship of the new government. He had lost much of his hold on the Liberals, especially of the grain growing provinces, by his sudden switching over to high protection in 1897 , and by his adherence to protection of the type dictated by the Manufacturers' Association. Moreover, in 1917, the old Liberal party in the house of commons became divided on the conscription bill much as the Liberal party at Westminster was divided over Gladstone's home rule bill of 1886 . Laurier went with the minority against conscription-a minority largely composed of Liberals from the province of Quebec; and his attitude towards the bill and the attitude of the French-Canadian Liberals made it impossible that Laurier, despite his long service as premier and his much longer service in the house of commons, could be acceptable as leader of the Unionist government.

Cabinet and ministerial places in the new government were, at its organization, almost equally divided between Conservatives and Liberals. A place was found in the cabinet for one representative of the grain growers; and there were included seven or eight men who had not hitherto been of the house of commons. Two or three of these ministers were altogether new to political life. The other newcomers to Ottawa were men who had seen some service in legislatures or in governments at the political capitals of the provinces. The new administration was consequently very much of a "Who's Who" body; and the first session of the new parliament disclosed no member of the cabinet as a man of outstanding political ability.

Neither for members' on the treasury bench, nor for members supporting the Unionist government, nor for members of the opposition led by Laurier, did the session offer many parliamentary opportunities. Throughout there was a disposition, especially in the last four or five weeks, to hurry business in order that the premier and several of the ministers might leave for London at the end of May; and judging from the attendance in the public galleries and the space assigned to parliamentary reports in the daily newspapers, there was unusually little popular interest in the proceedings of the new house of commons.

It soon became obvious that the opposition had accepted the conscription act - that it had come to the conclusion that the act had been endorsed by the great majority of the electors at the general election, and was not to be assailed. It was equally noticeable that the opposition was not disposed to raise any question, or at all events not to push any question, in such a way as to bring about a closer union of 
the parties-Conservatives, Liberals and grain growers' representatives - that are supporting the government. Evidently the conviction of the Liberals in opposition is that the union as it has existed since October, 1917 , is temporary. There would seem to be good grounds for this conviction; for as soon as the war comes to an end issues will be raised, especially in the grain-growing provinces, that threaten to divide the electorate quite as sharply as it was divided from 1879-1896-the years in which the Liberals were continuously and persistently assailing the protectionist policy of the Conservatives, and in national and other conventions pledging the party to sweep away the last vestige of the protectionist system to which the Conservatives, under the leadership of Macdonald, had committed the Dominion.

It is in the west-the country between the Great Lakes and the Rocky Mountains-that the campaigns for drastic economy, higher ethical standards in Dominion politics, and against protectionist tariffs, framed in the past by both political parties at the dictation of the manufacturers, will be launched at the end of the war. The grain growers are well organized. Much political achievement of a negative as well as of a positive character had accrued to their credit in the decade before the war. The farmers of Ontario are becoming almost equally well organized. They are associated with the grain growers of the western provinces in their political movement; and after the war the propaganda of the grain growers and the Ontario farmers is to be pushed in Quebec, and also in the Maritime Provinces. Both the grain growers and the Ontario farmers are well served by the weekly journals that are of the new agrarian movement; and the organized manufacturers who had matters pretty much their own way for seventeen years before 1914, are today more seriously concerned over the attack on the high tariff that is now threatening than they were over any attack between 1897 and the beginning of the war.

The legislation of the session of 1918 included an act conferring the electoral franchise on women, and an act making some sweeping changes in the organization of the civil service. A motion was also passed by the house of commons endorsing unanimously a minute of council in which the colonial office in Downing Street was informed that the cabinet and house of commons at Ottawa desired that the crown should confer no more hereditary distinctions, such as baronetcies and peerages, on Canadians domiciled in the Dominion. Canadians generally never appreciated the conferring of these distinctions on Canadians. They were not regarded as desirable links of empire. They 
were considered anti-social and antagonistic to the democratic conditions and traditions of the country. Recent bestowals of baronetcies and peerages on Canadians of great wealth-pushing, self-advertising men, of the bounder type-brought matters to a head; and the imperial government was faced with one of the most awkward colonial questions since Galt, in 1859, told the Duke of Newcastle that if as colonial secretary he counseled the cabinet to advise the queen to disallow the protectionist tariff enacted by the legislature of the united provinces in that year, the government in London had better send out troops to put the colony under military rule.

To students of political science, perhaps, the most noteworthy developments of the session and in the history of the Unionist government to the end of the session of 1918 arose out of the free use of orders in council by the government. By one of these orders, which had all the appearance of having been framed to help the Unionist government over a difficulty which was confronting them midway in the electoral campaign-by an audacious use of the power of order in council--a most important variation was made in the conscription act of 1917, a variation for which there would seem to have been no statutory warrant. Pressure for men for the military forces resulted in the cancellation of this order in council before the session was many weeks old; and when the constitutional history of Canada during the war comes to be written, the closest attention will have to be given to the free and in at least one instance extraordinary use to which the Unionist government put that most undemocratic instrument-the order in council. Then it will be expedient to ascertain why the order issued midway in the electoral campaign was deemed necessary; and also what action the Duke of Devonshire, the governor-general, took in regard to this particular order; for if the governor-general exercises any one function that is more constitutionally important than another, it is the function of seeing that there are no unwarranted departures from constitutional rules and usages-of seeing that the game is played strictly in accordance with the rules.

In any study of the working of representative institutions at Ottawa under war-time conditions, some attention will also have to be bestowed on a singular retrograde development that marked the 1918 session of the house of commons. For weeks there stood on the order paper a resolution, which, if the government had pressed it and it had been carried by the house, would have thrown upon the speaker the onerous and disturbing duty of censoring speeches made in the 
house before their publication in the parliamentary debates. There have accrued to the speakership at Ottawa most of the usages and traditions that since the middle years of the eighteenth century have attached to the great office of speaker of the house of commons at Westminster. As an office it approximates closely to the speakership of the house of commons of the imperial Parliament. At Westminster it is the usage that the speaker must not be nominated from the treasury bench. At Ottawa there is no such usage. The speaker is and always has been since the era of responsible government began the nominee of the government; and his election is proposed from the treasury bench. Thereafter his association or connection with the government is supposed to come to an end. He is not a partisan supporter of the government; and his position towards the house, and towards political parties in the house, becomes much the same as that of the speaker at Westminster.

But the resolution that was so long on the order paper at Ottawa disclosed one or other of two conditions, neither favorable to the dignity or position of the chair. It disclosed either that a relationship hat been established between the government and the speaker that was adverse to all the honored traditions associated with the chair, and adverse to the good order and discipline of the house; or that the speaker, without being consulted by the government, was willing that the government should jeopardize the position of the chair in the estimation of the house of commons and also of the constituencies. The government for some reason or other did not press the resolution in the house. To have done so would have given the opposition a provoking and legitimate opportunity of driving a wedge deep into the coalition. From any point of view the episode was regrettable; and it was unfortunate that the speaker did not, so far as can be ascertained from the official reports of the proceedings of the house, dissociate himself from the obnoxious resolution, and the inferences as regards the chair which its presence so long on the order paper suggested.

It is to the interest of the Dominion, and also to the interest of the Allies, that the existing coalition at Ottawa should continue at least until the end of the war. But more tact will be needed than was evidenced in the framing of this resolution, if the coalition is to continue working smoothly and effectively until the world is again at peace.

\section{Edward Porrit't.}

Hartford, Conn. 